\title{
ANALISIS PENERAPAN METODE PENCATATAN DAN PENILAIAN ATAS PERSEDIAAN BARANG DAGANG MENURUT PSAK NO 14 REVISI TAHUN 2012 PADA PT. BUMI PEMBANGUNAN PERTIWI
}

\author{
Arik Wijayani ${ }^{1)}$ \\ arikwijayanti@gmail.com \\ Universitas PGRI Madiun, Indonesia
}

\begin{abstract}
Inventory is an important thing for the company because most of the company's assets embedded in inventories. Problems are often experienced in accounting for inventories is the recording and assessment. The purpose of research at PT. Bumi Pertiwi Development is to investigate the suitability of the application of the method of recording and valuation of inventory at PT . Bumi Pertiwi Development with Statement of Financial Accounting Standards ( SFAS) No. 14 Revised 2012.This study uses a qualitative method. Data collection techniques with interviews and observations and documentation, and then analyzed using methods deskripstif and comparing the application of methods of recording and valuation of merchandise inventory PT. Bumi Pertiwi Development with IAS 14 Revised in 2012 . The study concluded that the method of recording using perpectual methods and methods of assessment using the average method. Inventory recording method applied by PT. Bumi Pertiwi Development is not in accordance with IAS 14 Revised, 2012. While inventory valuation method PT. Bumi Pertiwi development is in accordance with IAS 14 Revised 2012. Keywords : methods of recording perpectual, average valuation methods and PT . Bumi Pertiwi Development
\end{abstract}

\begin{abstract}
ABSTRAK
Persediaan merupakan suatu yang penting bagi perusahaan karena sebagian besar aktiva perusahaan tertanam pada persediaan. Masalah yang sering dialami dalam akuntansi persediaan adalah pencatatan dan penilaian. Tujuan dilakukan penelitian pada PT. Bumi Pembangunan Pertiwi adalah untuk mengetahui adanya kesesuaian penerapan metode pencatatan dan penilaian persediaan barang di PT. Bumi Pembangunan Pertiwi dengan Pernyataan Standar Akuntansi Keuangan (PSAK) No.14 Revisi tahun 2012. Penelitian ini menggunakan metode kualitatif.Teknik pengumpulan data dengan wawancara dan pengamatan serta dokumentasi, kemudian dilakukan analisis menggunakan metode deskripstif dan membandingkan penerapan metode pencatatan dan penilaian persediaan barang dagang PT. Bumi Pembangunan Pertiwi dengan PSAK No.14 Revisi Tahun 2012. Penelitian ini menyimpulkan bahwa metode pencatatan menggunakan metode perpectual dan metode penilaiannya menggunakan metode average. Metode pencatatan persediaan barang yang diterapkan oleh PT. Bumi Pembangunan Pertiwiada yang tidak sesuai dengan PSAK No.14 Revisi Tahun 2012. Sedangkan metode penilaian persediaan PT. Bumi Pembangunan Pertiwi sudah sesuai dengan PSAK No.14 Revisi Tahun 2012. Kata kunci: metode pencatatanperpectual, metode penilaian average dan PT. Bumi Pembangunan Pertiwi
\end{abstract}

\section{PENDAHULUAN}

Persediaan (Inventory), merupakan aktiva perusahaan yang menempati posisi yang cukup penting dalam suatu perusahaan, baik itu perusahaan dagang maupun perusahaan industri (manufaktur), Persediaan adalah pospos aktiva yang dimiliki oleh perusahaan untuk dijual dalam operasi bisnis normal (Kieso, Weygandt, and warfield, 2008:402).Dalam laporan keuangan, persediaan merupakan hal yang sangat penting karena baik laporan Rugi/Laba maupun Neraca tidak akan dapat disusun tanpa mengetahui nilai persediaan. Pada laporan neraca saldo perusahaan dagang, persediaan adalah salah satu aktiva lancar yang mempunyai nilai investasi terbesar, sehingga dari hal tersebut di atas kita dapat mengetahui betapa pentingnya persediaan bagi suatu perusahaan. Kesalahan dalam penilaian persediaan akan langsung berakibat kesalahan dalam laporan Rugi/Laba maupun neraca.PT. Bumi Pembangunan Pertiwi yang beralamat di jalan raya Nglames $\mathrm{km} 5$ 
Madiun termasuk perusahaan dagang yang bergerak dalam bidangdistribusi barang (distributor). Sebagai distributor harus mempunyai persediaan barang dagangan yang cukup banyak dan siap untuk dijual kepada pihak pengecer dan toko.

Ada dua metode pencatatan yaitu metode pencatatan periodic dan metode pencatatan perpectual. Untuk metode pencatatan periodik biasanya setiap terjadi penjualan tidak perlu dilakukan pencatatan harga pokok penjualan karena harga pokok penjualan dihitung pada akhir periode secara agregat.Sehingga jika perusahaan menggunakan metode periodic tidak bisa mengetahui harga pokok per transaksi. Sebagai sebuah usaha dagang yang bergerak di bidang distributor,metode pencatatan yang digunakan perusahaan menggunakan metode perpectual karena memudahkan perusahaan untuk mengontrol persediaan dan menghitung harga pokok penjualan per transaksi.Untuk mendapatkan nilai persediaan secara perpectual perusahaan mencatat transaksi pembelian barang dagangan langsung dicatat pada rekening persediaan disebelah debet dan penjualan barang dagangan dicatat pada rekening sebelah kredit. Metode pencatatan ini dibantu dengan buku pembantu persediaan barang dagangan dengan membuat kartu persediaan barang (stock card).

Perusahaan juga melakukan stock opname setiap bulan. Ketika Perusahaan melakukan stock opname hampir setiap bulan menghadapi masalah-masalah yang berkaitan dengan persediaan barang dagang. Sering terjadi perbedaan jumlah fisik persediaan barang dagang yang terdapat digudang dengan jumlah yang tercatat dalam buku stock persediaan barang dagang. Ada beberapa kemungkinan yang menyebabkan selisih stok persediaan antara lain adalah faktor kelalaian dan kurang koordinasi pada custumer service dengan pihak gudang adanya retur penjulan. Pada saat adanya retur penjualan seharusnya pihak gudang membuatkan FRC (form retur custumer), PBP (bukti penerimaan barang) atau bisa juga dari pihak customer service membatalkan transaksi penjualan dan menginput ulang transaksi penjualan sesuai dengan barang yang diterima pembeli. Perusahaan menambahkan biaya lain-lain untuk pencatatan retur pembelian.Yang dimaksud biaya lain-lain adalah biaya selisih harga karena disetiap periode pembelian terkadang harga pembelian barang ke pabrik berbedabeda. Akiabatnya ketika ada retur pembelian perusahaan mencatat selisih harga tersebut disisi sebelah kredit dengan keterangan biaya lain-lain. Sedangkan untuk retur penjualan hanya mencatat disisi sebelah debet retur penjualan dan kas disisi sebelah kredit.

Metode penilaian persediaan ada 3 macam metode yaitu metode $L I F O, F I F O$, dan Average. Produk yang di pasarkan PT. Bumi Pembangunan Pertiwi adalah produk semen yang barangnya cenderung mudah mengeras dan tidak bisa tahan lama. Setiap bulan program dari pabrik berbeda, mengakibatkan berpengaruh pada harga pokok pembelian dan harga pokok penjualan. Oleh karena itu metode yang digunakan untuk penilaian adalah biaya rata-rata (average). Perusahaan menggunakan metode penilaian average agar memudahkan menghitung harga pokok penjualan per unit dan mengurangi risiko kerugian karena perbedaan harga pokok pembelian setiap periode berbeda-beda. Jika perusahaan menggunakan metode FIFO dan LIFO perusahaan lebih sulit untuk menghitung harga pokok per unit barang dan cenderung mendapatkan laba sedikit.

Menurut PSAK NO 14 Revisi tahun 2012, dalam paragraf no 16 merangkan contoh-contoh biaya yang dikeluarkan dari biaya persediaan dan diakui sebagai beban dalam periode terjadinya adalah:

a) jumlah pemborosan bahan, tenaga kerja, atau biaya produksi lainnya yang tidak normal; 
b) biaya penyimpanan, kecuali biaya tersebut diperlukan dalam proses produksi sebelum dilanjutkan pada tahap produksi berikutnya;

c) biaya administrasi dan umum yang tidak memberikan kontribusi untuk membuat persediaan berada dalam kondisi dan lokasi saat ini; dan

d) biaya penjualan.

Sebagai perusahaan dagang masalah yang dihadapi perusahaan tidak adanya biaya penyimpanan barang dagangan, biaya yang dimaksud antara lain biaya kerusakan barang, biaya asuransi persediaan dan biaya kehilangan akibat pencurian. Akibatnya jika ada kerusakan barang atau kehilangan barang akan dibebankan pada kepala gudang yang bersangkutan.

Dalam wawancara terhadap beberapa pelanggan yang bertransaksi dengan perusahaan rata-rata komplain masalah biaya angkut yang tidak konsisten. Biaya angkut penurunan barang tidak dicatat dengan faktur penjualan. Akibatnya ada beberapa tenaga kerja angkut yang mematok biaya angkut tidak sesuai dengan ketentuan perusahaan. Untuk biaya angkut penjulan perusahaan hanya mencatat biaya yang dikelurkan untuk biaya bahan bakar minyak (BBM) tergantung jarak yang ditempuh dari gudang sampai ke toko yang dituju. Sehingga perusahaan membebankan ongkos angkut kepada pemilik toko.

Metode pengukuran persediaan menurut PSAK NO 14 Revisi tahun 2012 adalah biaya persediaan yang meliputi semua biaya pembelian, biaya konversi, dan biaya lain-lain. Sedangkan perusahaan hanya mencatat biaya pembelian yang meliputi biaya harga beli dan biaya pajak.

Pemilihan metode akuntansi persediaan yang tepat sangat diperlukan dalam suatu perusahaan. Metode pencatatan dan penilaian persediaan yang diterapkan disetiap perusahaan berbeda- beda dan tidak semuanya sesuai dengan ketentuan yang berlaku, dalam hal ini mengacu padaStandar Akuntansi Keuangan yang berlaku di Indonesia. Pada Pernyataan Standar Akuntansi Keuangan (PSAK) No.14 Revisi Tahun 2012 dijelaskan tentang berbagai hal yang berhubungan dengan persediaan, diantaranya pengukuran persediaan dan metode apa saja yang boleh digunakan dalam penilaian persediaan. Oleh karena itu peneliti tertarik untuk meneliti dan membahas akuntansi persediaan pada PT. Bumi Pembangunan Pertiwi yaitu dengan menganalisa penerapan metode pencatatan dan penilaiaan atas persediaan barang dagang menurut PSAK No. 14 Tahun 2012. Tujuan dari penelitian ini adalah:

1. Untuk mengetahui metode pencatatan dan penilaian persediaan barang dagang yang diterapakan pada PT. Bumi Pembangunan Pertiwi.

2. Untuk mengetahui kebijakan perusahaan dalam pencatatan dan penilaian persediaan barang dagang sudah sesuai dengan PSAK No. 14 Revisi tahun 2012.

\section{KAJIAN TEORI \\ Persediaan}

Ikatan Akuntansi Indonesia (2012:14.2) mengemukakan bahwaPersediaan adalah aset:

a. Tersedia untuk dijual dalam kegiatan usaha biasa

b. Dalam proses produksi untuk penjualan tersebut; atau

c. Dalam bentuk bahan atau perlengkapan untuk digunakan dalam proses produksi atau pemberian jasa.

Pendapat Warren, Reeve, dan Fess (2005:440) mengatakan persediaan adalah "Barang dagang yang disimpan untuk dijual dalam operasi bisnis perusahan, dan bahan yang digunakan dalam proses produksi atau disimpan untuk tujuan itu". Persediaan yang diperoleh perusahaan langsung dijual kembali 
tanpa mengalami proses produksi selanjutnya disebut persediaan barang dagang.

Menurut pernyataan Nikmatul Salamah (2012:11) menerangkan persediaan pada setiap perusahaan berbeda dengan perusahaan lain tergantung pada bidang kegiatan bisnisnya. Persediaan dapat diklasifikasikan sebagai berikut:

1. Persediaan barang dagangan (merchandise inventory)

2. Persediaan manufaktur (manufacturing inventory)

Persediaan itu dapat dibedakan atau dikelompokkan menurut jenis dan posisi barang di dalam urutan pengerjaan produk, yaitu:

a. Persediaan bahan baku ( Row materials stock)

b. Persediaan barang dalam proses (work in process/progress stock)

c. Persediaan barang jadi (Finished good stock)

Selain jenis-jenis persediaan yang telah dijelaskan diatas berdasarkan jenis, untuk perusahaan jasa persediaannya secara eksplisit sulit didefinisikan, namun persediannya dapat diartikan sebagai besarnya biaya jasa yang meliputi upah dan biaya personalia lainnya yang secara langsung belum dikeluarkan dalam menangani pemberian jasa.

PSAK No 14 Tahun 2012 mengatur bahwa "Persediaan harus diukur berdasarkan biaya atau nilai realisasi neto, mana yang lebih rendah" (paragraf 9).Biaya persediaan meliputi semua biaya pembelian, biaya konversi dan biaya lain yang timbul sampai persediaan berada dalam kondisi dan lokasi saat ini "(paragraf 10).

Untuk perusahaan jasa persediaannya secara eksplisit sulit didefinisikan, namun persediannya dapat diartikan sebagai besarnya biaya jasa yang meliputi upah dan biaya personalia lainnya yang secara langsung belum dikeluarkan dalam menangani pemberian jasa. a. Biaya - biaya Persediaan

PSAK No 14 Tahun 2012 mengatur bahwa "Persediaan harus diukur berdasarkan biaya atau nilai realisasi neto, mana yang lebih rendah" (paragraf 9).

Biaya persediaan meliputi semua biaya pembelian, biaya konversi dan biaya lain yang timbul sampai persediaan berada dalam kondisi dan lokasi saat ini "(paragraf 10).

\section{b. Biaya-biaya lain}

Biaya-biaya lain hanya dibebankan sebagai biaya persediaan sepanjang biaya tersebut timbul agar persediaan berada dalam kondisi dan lokasi saat ini. Misalnya, dalam keadaan tertentu diperkenankan untukmemasukkan overhead nonproduksi atau biaya perancangan produk untuk pelanggan tertentu sebagai biaya persediaan“" (paragraf 15).

Dalam paragraf no. 16 menerangkan contoh-contoh biaya yang dikeluarkan dari biaya persediaan dan diakui sebagai beban dalam periode terjadinya adalah:

Jumlah pemborosan bahan, tenaga kerja, atau biaya produksi lainnya yang tidak normal:

1. Biaya penyimpanan, kecuali biaya tersebut diperlukan dalam proses produksi sebelum dilanjutkan pada tahap produksi berikutnya;

2. Biaya administrasi dan umum yang tidak memberikankontribusi untuk membuat persediaan berada dalam kondisi dan lokasi saat ini; dan

3. Biaya penjualan.

\section{Metode pencatatan}

Ada dua sistem yang dapat digunakan dalam hubungannya dengan pencatatan persediaan adalah:

a. Sistem pencatatan fisik/periodik (physical/ periodic inventory system). 
Menurut Tjahjono (2009:59) bahwa sistem akuntansi dapat dibedakan menjadi dua yaitu: sistem fisik (periodik) dan metode buku (perpetual). b. Sistem pencatatan persediaan menggunakan metode fisik, menurut Syafi'I Syakur Ahmad (2009;130) adalah sebagai berikut:

Tabel 2.1

Sistem Pencatatan Transaksi Metode Fisik/ Periodik

\begin{tabular}{|c|c|c|}
\hline Keterangan / Transaksi & \multicolumn{2}{|c|}{ Metode Fisik / Periodik } \\
\hline \multirow{2}{*}{$\begin{array}{l}\text { Pembelian barang dagangan tunai / } \\
\text { kredit }\end{array}$} & Pembelian & $\mathrm{XxX}$ \\
\hline & Kas / Utang dagang & $\mathrm{XXX}$ \\
\hline \multirow{2}{*}{ Retur pembelian } & Kas/ Utang dagang & $\mathrm{xxx}$ \\
\hline & Retur pembelian & $\mathrm{xxx}$ \\
\hline \multirow{2}{*}{ Potongan pemblian } & Kas & $\mathrm{xxx}$ \\
\hline & Potongan pembelian & $\mathrm{xxx}$ \\
\hline Beban angkut pembelian & $\begin{array}{l}\text { Beban angkut pembelian } \\
\text { Kas }\end{array}$ & $\begin{array}{l}\mathrm{XXX} \\
\mathrm{XXX}\end{array}$ \\
\hline Penjualan tunai / kredit & $\begin{array}{l}\text { Kas / Piutang dagang } \\
\text { Penjualan }\end{array}$ & $\begin{array}{l}\mathrm{XXX} \\
\mathrm{XXX}\end{array}$ \\
\hline Retur penjualan & $\begin{array}{l}\text { Retur penjualan } \\
\text { Kas / Piutang dagang }\end{array}$ & $\begin{array}{l}\mathrm{XXX} \\
\mathrm{XXX}\end{array}$ \\
\hline Potongan penjualan & $\begin{array}{l}\text { Potongan penjualan } \\
\text { Kas }\end{array}$ & $\begin{array}{l}\mathrm{XXX} \\
\mathrm{XXX}\end{array}$ \\
\hline Beban angkut penjualan & $\begin{array}{l}\text { Beban angkut penjualan } \\
\text { Kas }\end{array}$ & $\begin{array}{l}\mathrm{xxx} \\
\mathrm{Xxx}\end{array}$ \\
\hline \multicolumn{3}{|c|}{$\begin{array}{l}\text { Sumber: Syafi'I Syakur Ahmad (2009;130) } \\
\text { istem Pencatatan persediaan secara } \\
\text { ermanen/perpetual (perpetual } \\
\text { nventory system)Ely Suhayati dan } \\
\text { iri Dewi Anggadini (2009:226) } \\
\text { nenyatakan bahwa sistem perpetual } \\
\text { Sistem Pencatatan Transaksi Metode Perpectual }\end{array}$} \\
\hline Keterangan / Transaksi & Metode perpectual & \\
\hline \multirow{2}{*}{$\begin{array}{l}\text { Pembelian barang dagangan } \\
\text { tunai / kredit } \\
\text { Retur pembelian }\end{array}$} & $\begin{array}{l}\text { Persediaan barang dagang } \mathrm{xx} \\
\text { Kas / Uatang dagang }\end{array}$ & XXX \\
\hline & $\begin{array}{l}\text { Kas / Utang dagang } \\
\text { Persediaan barang dagang }\end{array}$ & $\mathrm{xxx}$ \\
\hline Potongan pemblian & $\begin{array}{l}\text { Kas } \\
\text { Persediaan barang daganga }\end{array}$ & $\begin{array}{l}\mathrm{xxx} \\
\text { an } \mathrm{xxx}\end{array}$ \\
\hline Beban angkut pembelian & $\begin{array}{l}\text { Persediaan barang dagang } \mathrm{x} \\
\text { Kas }\end{array}$ & $\begin{array}{l}\mathrm{XXX} \\
\mathrm{XXX}\end{array}$ \\
\hline Penjualan tunai / kredit & $\begin{array}{l}\text { Kas / Piutang dagang } \\
\text { Penjualan } \\
\text { Harga pokok penjualan }\end{array}$ & $\begin{array}{l}\mathrm{XXX} \\
\mathrm{XXX}\end{array}$ \\
\hline
\end{tabular}




\begin{tabular}{lcc}
\hline & \multicolumn{1}{c}{ Persediaan barang gadangan $\mathrm{xxx}$} \\
Retur penjualan & Retur penjualan & $\mathrm{xxx}$ \\
& Kas piutang dadang & $\mathrm{xxx}$ \\
& Persediaan barang dagang & $\mathrm{xxx}$ \\
Potongan penjualan & Harga pokok penjualan & $\mathrm{xxx}$ \\
& Potongan penjualan & $\mathrm{xxx}$ \\
Beban angkut penjualan & Kas & $\mathrm{xxx}$ \\
& Beban angkut penjualan & $\mathrm{xxx}$ \\
& Kas & $\mathrm{xxx}$ \\
\hline
\end{tabular}

Sumber: Syafi'I Syakur Ahmad (2009;130)

\section{Metode Penilaian}

Stice dan Skousen (2009:667) ada beberapa macam metode penilaian persediaan yang umum digunakan yaitu: identifikasi khusus, biaya rata-rata (average), masuk pertama, keluar pertama (FIFO) dan masuk terakhir, keluar pertama (LIFO).

Pernyataan Standar Akuntansi Keuangan No. 14 (PSAK No.14) Revisi tahun 2012 tentang Persediaan

PSAK adalah standar yang harus diikuti dalam pencatatan dan pelaporan akuntansi di Indonesia.PSAK ini merupakan aturan-aturan yang harus ditaati oleh para akuntan agar pelaporan akuntansi di Indonesia ini menjadi lebih efektif.

a. Tujuan

Tujuan Pernyataan ini adalah mengatur perlakuan akuntansi untuk persediaan. Permasalahan pokok dalam akuntansi persediaan adalah penentuan jumlah biaya yang diakui sebagai aset dan perlakuan akuntansi selanjutnya atas aset tersebut sampai pendapatan terkait diakui. Pernyataan ini menyediakan panduan dalam menentuan biaya dan pengakuan selanjutnya sebagai beban, termasuk setiap penurunan menjadi nilai realisasi neto. Pernyataan ini juga memberikan panduan rumus biaya yang digunakan untuk menentukan biaya persediaan "(paragraf 01)".

b. Ruang lingkup

Dalam paragraf 02 PSAK NO 14 pernyataan ini diterapkan untuk semua persediaan, kecuali:

1. Pekerjaan dalam proses yang timbul dalam kontrak kontruksi (construction contracts).

2. Instrumen keuangan.

3. Persediaan yang dimiliki oleh produsen peternakan, produk pertanian dan kehutanan, dan hasil tambang sepanjang persediaan tersebut dinilai berdasarkan nilai realisasi bersih sesuai dengan kelaziman praktek yang berlaku dalam industri tertentu.

Dalam paragraf 03 pernyataan ini tidak diterapkan untuk pengukuran persediaan yang dimiliki oleh :

1. Produsen produk agrikultural dan kehutanan, hasil agrikultural setelah panen, mineral dan produk mineral, sepanjang persediaan tersebut diukur pada nilai realisasi netto sesuai dengan praktik yang berlaku di industri tersebut. Jika persediaan diukur pada nilai 
realisasi neto, maka perubahan nilaai tersebut diakui dalam laba rugi pada periode terjadi.

2. Pialang pedagang komoditi yang mengukur persediaan pada nilai wajar dikurangi biaya untuk menjual. Jika persediaan tersebut diukur pada nilai wajar dikurangi biaya untuk menjual, maka perubahan nilai wajar dikurangi biaya untuk menjual diakui dalam laba rugi pada periode terjadi.

Dalam pargraf 6 menjelaskan definisi persediaan, nilai realisasi wajar dan nilai realisasi netto.

1. Persediaan adalah aset:

a. Tersedia dijual

b. Dalam proses produksi untuk penjualan tersebut

c. Dalam bentuk bahan atau perlengkapan untuk digunakan dalamproses produksi atau pemberian jasa

2. Nilai realisasi netto adalah estimasi harga jual dalam kegiatan usaha biasa dikurangi estimasi biaya penyelesaian dan estimasi biaya yang diperlukan untuk membuat penjulan.

3. Nilai wajar jumlah suatu aset dipertukarkan atau liabilitas diselesaikan antara pihak-pihak yang berkeinginan dan memiliki pengetahuan memadahi dalam suatu transaksi.

Dalam paragraf 09 menerangakan persediaan dikukur berdasarkan biaya perolehan atau nilai realisasi netto, mana yang lebih rendah.

Dalam paragraf 10 menerangakan biya persediaan meliputi semua biaya pembelian biaya konversi dan biaya lain yang timbul sampai persediaan berda dalam kondisi dan lokasi saat ini

\section{KERANGKA PIKIR}

Berdasarkan uraian kajian teori di atas, maka model kerangka pikir yang digunakan untuk memudahkan pemahaman konsep yang digunakan sebagai berikut :

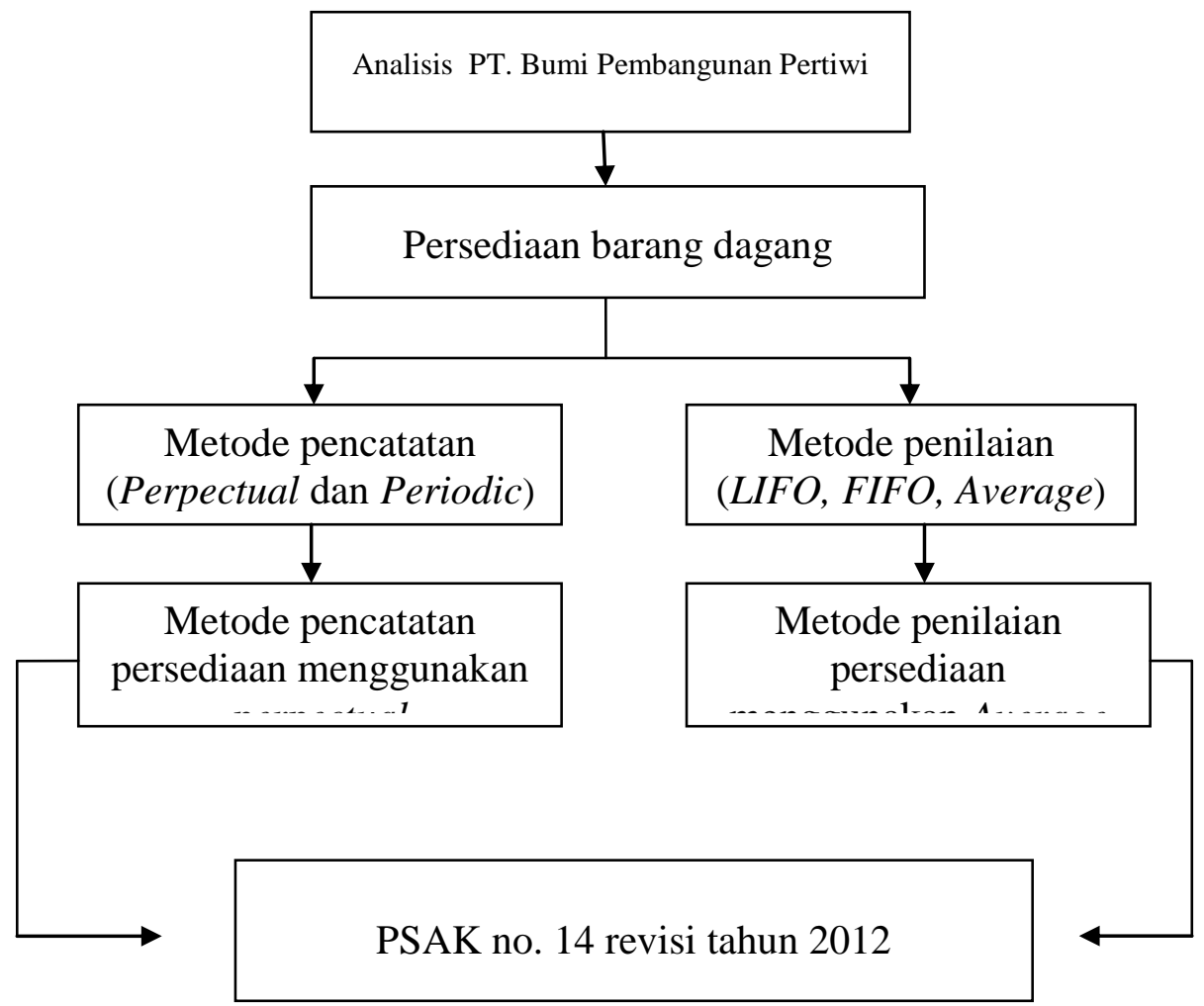




\section{METODE PENELITIAN}

Penelitian ini menggunakan
pendekatan kualitatif dimana dalam penelitian yang dilakukan bersifat deskriptif yaitu untuk mengetahui atau menggambarkan kenyataan dari kejadian yang diteliti sehingga memudahkan penulis untuk mendapatkan data yang objektif dalam rangka mengetahui dan memahami metode pencatatan dan penilaian persediaan barang yang diterapkan di PT. Bumi Pembangunan Pertiwi.

Populasi penelian ini adalah PT. Bumi Pembangunan Pertiwi. Sampel penelitian ini adalah Laporan keuangan bulan Desember tahun 2014, laporan buku stock persediaan dan kebijakan akuntansi yang digunakan perusahaan.

Sumber data yang digunakan adalah data primer dan data sekunder. Data Primer penelitian ini adalah data yang belum di olah yang di peroleh langsung dari PT. Bumi Pembangunan Pertiwi, seperti hasil tanya jawab langsung kepada pihak accounting dan bagian gudang yang berhubungan langsung dengan pencatatan dan penilaian persediaan barang dagangan . Data sekunder penelitian ini adalah data laporan stock persediaan dan laporan keuangan bulan Desember 2014.Penelitian ini menggunakan teknik pengumpulan data sebagai berikut:

1. Penelitian Lapangan (field research)

a) Interview (wawancara)

b) Observasi

c) Dokumentasi.

2. PenelitianKepustakaan

Penelitian ini menganalisis data dengan menggunakan dua cara yaitu :

a. Metode deskriptif adalah metode penelitian yang ditujukan untuk menggambarkan fenomena-fenomena yang ada, yang berlangsung pada saat ini atau saat yang lampau (Syaodih, 2009:54).

b. Membandingkan metode pencatatan dan penilaiaan persediaan barang yang telah diterapkan oleh PT. Bumi pembangunan Pertiwi dengan alat analisis yang digunakan dalam pembahasan dan pengelolaan data yang sesuai dengan PSAK No. 14 revisi tahun 2012.

\section{HASIL DAN PEMBAHASAN}

Metode Pencatatan Persediaan Barang

a) Pembelian Persediaan Barang

Metode pencatatan persediaan pada

PT Bumi Pembangunan Pertiwi

mengunakan sistem pencatatan

persediaan perpetual, yaitu dapat dilihat dari penyajian laporan keuangannya. Perusahaan mempunyai 2 sistem pembelian barang dagangan yaitu pembelian secara kredit dan tunai. Untuk mencatat pembelian barang dagang secara tunai perusahaan mencatatnya dalam jurnalsebagai berikut:

Persediaan barang dagangan $\quad$ xxx PPN Masukan $\quad x x x$ Kas $\quad$ Xxx Sedangkan untuk mencatat pembelian barang dagang secara kredit jurnalnya adalah:

Persediaan barang dagangan $\quad \mathrm{xxx}$ PPN Masukan $\quad$ Xxx Utang dagang $\quad$ XXX

\section{b) Penjualan Barang Dagang}

Produk yang dijualPT. Bumi Pembangunan Pertiwimempunyai 2 sistem pembayaran yaitu secara tunai dan kredit. Untuk pembayaran secara kredit, PT Bumi pembangunan pertiwi mempunyai beberapa term ofpayments yaitu : 30 hari dan maksimum 45 hari dimulai saat invoice di cetak ataupun saat invoice diterima pelanggan. Sedangkan pembayaran dalam jangka waktu 3 hari, 7 hari dan 14 hari masih bisa mendapatkan potongan kontan.Untuk penjualan secara tunai dengan pembayaran secara langsung maka jurnalnya sebagai berikut: Harga Pokok Penjualan xxx 
Kas

$\mathrm{XXX}$

Persediaan Barang Dagangan xxx

PPN Keluaran

Penjualan

XXX

Sedangkan penjualan secara tunai dengan

term of payment 3 hari sampai 14 hari maka

jurnalnya adalah sebagai berikut:

Harga Pokok Penjualan

$\mathrm{XXX}$

Piutang Usaha

$\mathrm{XXX}$

Persediaan Barang Dagangan xxx

PPN Keluaran

$\mathrm{XXX}$

Penjualan

$\mathrm{XXX}$

Jika terjadi penjualan secara kredit, maka

perusahaan akan mencatat jurnal sebagai

berikut

Harga Pokok Penjualan $\quad$ xxx

Piutang Usaha xxx

Persediaan Barang Dagangan Rp xxx

PPN Keluaran

$\operatorname{Rp} x x x$

Penjualan

\section{c) Biaya Angkut}

$\operatorname{Rp} x x x$

Pada PT Bumi Pembangunan Pertiwi tidak mencatat biaya angkut karena ketika perusahaan membeli barang dagang dari pabrik sudah merupakan harga pokok pembelian.Biaya yang dikeluarkan perusahaan hanya biaya bongkar muat semen yang berada di gudang. Tetapi untuk produk yang akan di antar ke Toko, hanya dikenakan biaya bahan bakar minyak (BBM) tergantung jarak yang ditempuh untuk mencapai toko tersebut. Sedangkan biaya bongkar muat semen / ongkos angkut semen ditanggung oleh customer. Untuk biaya BBM di masukkan dalam kategori biaya pemasaran maka jurnalnya adalah sebagai berikut:

Biaya Bensin/Solar/Oli (Biaya Pemasaran) $\quad$ xxx

Kas $\quad \mathrm{xxx}$

Untuk biaya bongkar muat semen

yang berada digudang perusahaan

mencatat

Biaya Bongkar Muat Semen xxx

Kas $\quad$ Xxx

Menurut PSAK 14 Revisi Tahun 2012 jurnal pencatatan beban angkut adalah sebagai berikut:

Biaya Angkut masuk

Persediaan barang Rp xxx Kas

$\operatorname{Rp} \times x x$

Biaya Angkut keluar

Biaya angkut keluar Rp xxx

Kas

$\operatorname{Rp} x x x$

\section{d) Pencatatan Retur}

\section{Retur Pembelian}

Jika perusahaan melakukan pembelian tetapi barang tersebut tidak sesuai dengan PO (Purchase Order) yang dibuat, maka perusahaan berhak untuk meretur barang tersebut. Akibat sering terjadinya retur barang yang dikirim dari pabrik tidak sesuai PO (Purchase Order). Maka dari itu perusahaan melakukan retur. Untuk mencatat retur pembelian perusahaan mencatat dengan jurnal sebagai berikut:

Hutang Usaha xxx

Persediaan Barang Dagang $\mathrm{xxx}$ PPN Masukan $\quad x x x$ Biaya-biaya lain $\quad \mathrm{xxx}$

\section{Retur Penjualan}

Ketika perusahaan melakukan penjualan ke customer ada beberapa customer yang komplain karena barang yang dikirim kondisinya kurang bagus. Oleh karena itu perusahaan melakukan kebijakan untuk meretur kembali barang yang kurang bagus tersebut. Untuk proses retur penjualan perusahaan menerapkan 3 cara yaitu dari pihak kepala gudang membuat Form BPB (Bukti Penerimaan Barang), atau Form FRC (Form Retur Customer) dan bagian customer service perusahaan 
melakukan pembatalan transaksi.

Untuk mempercepat proses invoice biasanya dari pihak customer service langsung melakukan pembatalan transaksi dan menginput ulang invoice sesuai dengan yang diterima customer. Kurangnya koordinasi kepala gudang dengan custumer service ketika adanya retur menyebabkan terjadi selisih stok. Karena dari pihak customer service membuatkan invoice sesuai dengan PO (Purchase Order) dari customer tersebut.

Untuk mencatat transaksi retur penjualan perusahaan mencatat dengan jurnal sebagai berikut:

Retur Penjualan xxx

Kas $\quad$ xxx

Metode Penilaian Persediaan Barang

Pengungkapan
Dalam melakukan penilaian terhadap persediaan barang PT. Bumi Pembangunan Pertiwi menggunakan asumsi metode average. Dalam metode ini harga pokok rata-rata dicatat setiap ada pembelian dan penjualan barang. Jadi setiap ada transaksi pembelian maupun penjulan barang dagang untuk stok dan harga pokok barang dagang sudah otomatis terhitung.

\section{Pengakuan Sebagai Beban}

PT. Bumi Pembangunan

Pertiwimenerapkan pengakuan sebagai beban pada saat terjadi penjualan barang secara kredit, yang dicatat dalam jurnal sebagai berikut:

$\begin{array}{cc}\text { Harga pokok } & \text { penjualan } \\ \text { Rp xxx } & \\ \text { Persediaan } & \text { barang } \\ \text { dagangan } & \text { Rp } \\ \text { xxx } & \end{array}$

Neraca PT. Bumi Pembangunan Pertiwi

(Di sajikan dalam Rupiah)

\begin{tabular}{|c|c|}
\hline \multicolumn{2}{|c|}{$\begin{array}{c}\text { Jalan Raya Nglames km } 5 \text { Madiun } \\
\text { Neraca Per } 31 \text { Desember } 2015\end{array}$} \\
\hline \multicolumn{2}{|l|}{ ASET } \\
\hline \multicolumn{2}{|l|}{ ASET LANCAR } \\
\hline Kas & 104.577.351.873 \\
\hline \multicolumn{2}{|l|}{ Kas di Bank } \\
\hline Bank CIMB & 102.070 .025 .326 \\
\hline Bank BCA & 1.535 .200 .435 \\
\hline Total kas Bank & 103.605 .225 .761 \\
\hline Surat-Surat Berharga & 4.114.600.562 \\
\hline \multicolumn{2}{|l|}{ Nilai Buku Piutang dagang } \\
\hline Piutang Usaha & 46.167 .790 .456 \\
\hline Cadangan Kerugian Piutang & 1.372 .828 .245 \\
\hline Total Nilai Buku Piutang Usaha & 44.794 .962 .211 \\
\hline Piutang lain-lain & 1.530 .000 .334 \\
\hline Persediaan Barang Dagangan & 24.113 .928 .562 \\
\hline Biaya Dibayar Dimuka & 5.704 .000 .362 \\
\hline PPN Masukan & 2.749 .552 .260 \\
\hline Total Aset Lancar & 291.189 .621 .925 \\
\hline ASET TETAP & \\
\hline
\end{tabular}


Harga Perolehan Aset tetap

Akumulasi Perolehan Aset Tetap

Total Aset Tetap

Total Aset

Kewajiban

Kewajiban Lancar

Hutang Usaha

Hutang Wesel

Hutang Lain-Lain

PPN Keluaran

Total Kewajiban Lancar

Kewajiban Jangka Panjang

Hutang Bank

Total Kewajiban jangka Panjang

Total Kewajiban

Nett Asset

Ekuitas

Modal Saham

Agio Saham

Laba Ditahan

Laba Perolehan Berjalan

Deviden

Laba (Rugi Penjualan Surat Bersih)

Laba (Rugi Pertukaran Asset)

Total Ekuitas
315.000.000.000

47.000.000.000

268.000 .000 .000

559.189 .621 .925

30.067 .915 .226

33.000 .000 .000

3.056 .000 .247

7.387.000.374

73.510 .915 .847

$\underline{128.000 .000 .000}$

\begin{tabular}{|c|c|}
\hline$\underline{128.000 .000 .000}$ & \\
\hline & 201.510 .915 .847 \\
\hline & 357.678 .706 .078 \\
\hline
\end{tabular}

183.376.635.378

122.000 .000 .000

52.941 .600 .000

15.175.069.750

18.000.000.000

1.885.401.625

300.000 .000 


\section{Laporan Laba-Rugi PT. Bumi Pembangunan Pertiwi (Di sajikan dalam Rupiah)}

\begin{tabular}{|c|c|c|}
\hline \multicolumn{3}{|c|}{$\begin{array}{c}\text { PT. Bumi Pembangunan Pertiwi } \\
\text { Jalan Raya Nglames km } 5 \text { Madiun } \\
\text { Laporan Laba/Rugi }\end{array}$} \\
\hline Ket & 2015 & \multirow[b]{5}{*}{75.110 .432 .246} \\
\hline Penjualan & 78.456.067.246 & \\
\hline Potongan Penjualan & 3.180 .635 .000 & \\
\hline Retur Penjualan & 165.000 .000 & \\
\hline Penjualan Bersih & & \\
\hline \multicolumn{3}{|l|}{$\begin{array}{l}\text { HARGA POKOK } \\
\text { PENJUALAN }\end{array}$} \\
\hline Persediaan awal & 1.418 .001 .043 & \\
\hline Pembelian & 77.537.379.034 & \\
\hline \multirow[t]{2}{*}{ Retur Pembelian } & 54.655 .795 & \\
\hline & 78.900 .724 .282 & \\
\hline $\begin{array}{l}\text { Persediaan akhir } \\
\text { HARGA POKOK }\end{array}$ & 24.113 .928 .562 & \\
\hline PENJUALAN & & 54.786 .795 .720 \\
\hline Laba Kotor & & 20.323 .636 .526 \\
\hline \multicolumn{3}{|l|}{ Biaya Pemasaran } \\
\hline Biaya Gaji+ THR & 1.340 .540 .750 & \\
\hline Biaya Perjalanan Dinas & 97.570 .000 & \\
\hline Biaya BBM & 138.970 .000 & \\
\hline Biaya Promosi & 1.098 .542 .325 & \\
\hline Biaya Sewa Gudang & 197.256 .760 & \\
\hline Biaya Kendaraan & 76.600 .000 & \\
\hline Biaya Alat tulis & 4.570 .000 & \\
\hline Biaya kerugian Piutang & 1.372 .828 .245 & \\
\hline Biaya Percetakan & 18.700 .000 & \\
\hline \multicolumn{3}{|l|}{ Biaya Umum dan Lain-Lain } \\
\hline Biaya PLN & 47.396 .423 & \\
\hline $\begin{array}{l}\text { Biaya Telepon/Fax } \\
\text { Biaya Pemeliharaan }\end{array}$ & 27.680 .542 & \\
\hline $\begin{array}{l}\text { Kendaraan } \\
\quad \text { Biaya Pemeliharaan }\end{array}$ & 57.000 .000 & \\
\hline Gedung & 11.400 .000 & \\
\hline Biaya Administrasi & 3.750 .000 & \\
\hline Biaya Bunga Berjalan & 450.000 .000 & \\
\hline Biaya umum lainnya & 29.540 .460 & \\
\hline \multirow[t]{2}{*}{ Total Biaya } & & 4.972.345.505 \\
\hline & & 15.351.291.021 \\
\hline Biaya Pajak & & $\underline{176.221 .316}$ \\
\hline
\end{tabular}


Perbandingan Pencatatan Pada Perusahaan dan PSAK No.14 Revisi 2012

\begin{tabular}{|c|c|c|c|}
\hline Metode & Perusahaan & PSAK No.14 & Keterangan \\
\hline \multirow[t]{6}{*}{ Pencatatan } & $\begin{array}{l}\text { Pembelian persediaan barang } \\
\text { (tunai) } \\
\text { Persediaan barang Rp xxx } \\
\text { PPN Masuakn Rp xxx } \\
\quad \text { Kas Rp xxx }\end{array}$ & $\begin{array}{l}\text { Pembelian persediaan barang } \\
\text { (tunai) } \\
\text { Persediaan barang Rp xxx } \\
\qquad \text { Kas Rp xxx }\end{array}$ & Sesuai \\
\hline & $\begin{array}{l}\text { Pembelian persediaan barang } \\
\text { (kredit) } \\
\text { Persediaan barangRp xxx } \\
\text { PPN Masukan Rp xxx } \\
\quad \text { Utang dagang Rp xxx }\end{array}$ & $\begin{array}{l}\text { Pembelian persediaan barang } \\
\text { (kredit) } \\
\text { Persediaan barangRp xxx } \\
\quad \text { Utang dagang Rp xxx }\end{array}$ & Sesuai \\
\hline & $\begin{array}{l}\text { Penjualan barang dagang (tunai) } \\
\text { HPP Rp xxx } \\
\text { Kas Rp xxx } \\
\text { Persediaan Rp xxx } \\
\text { PPN Keluaran Rp xxx } \\
\text { Penjualan Rp xxx }\end{array}$ & $\begin{array}{l}\text { Penjualan barang dagang } \\
\text { (tunai) } \\
\text { HPP Rp xxx } \\
\text { Kas Rp xxx } \\
\text { Persediaan Rp xxx } \\
\text { Penjualan Rp xxx }\end{array}$ & Sesuai \\
\hline & $\begin{array}{l}\text { Penjualan barang dagang } \\
\text { (kredit) } \\
\text { HPP Rp xxx } \\
\text { Piutang Rp xxx } \\
\text { Persediaan Rp xxx } \\
\text { PPN Keluaran Rp xxx } \\
\text { Penjualan Rp xxx }\end{array}$ & $\begin{array}{l}\text { Penjualan barang dagang } \\
\text { (kredit) } \\
\text { HPP Rp xxx } \\
\text { Kas Rp xxx } \\
\text { Persediaan Rp xxx } \\
\text { Penjualan Rp xxx }\end{array}$ & Sesuai \\
\hline & $\begin{array}{l}\text { Pencatatan Retur Pembelian } \\
\text { Hutang Dagang Rp xxx } \\
\text { Persediaan Rp xxx } \\
\text { PPN MasukanRp xxx } \\
\text { Biaya lain- lain Rp xxx }\end{array}$ & $\begin{array}{c}\text { Pencatatan Retur Pembelian } \\
\text { Kas/ Utang Dagang Rp xxx } \\
\text { Persediaan Rp xxx }\end{array}$ & $\begin{array}{l}\text { Tidak } \\
\text { sesuai }\end{array}$ \\
\hline & $\begin{array}{l}\text { Pencatatan Retur Penjualan } \\
\text { Retur Penjualan Rp xxx } \\
\text { Kas Rp xxx }\end{array}$ & $\begin{array}{l}\text { Pencatatan Retur Penjualan } \\
\text { Retur Penjualan Rp xxx } \\
\text { Kas Rp xxx } \\
\text { Persediaan Barang Rp xxx } \\
\text { Harga pokok Penjulan Rp } \\
\text { xxx }\end{array}$ & $\begin{array}{l}\text { Tidak } \\
\text { sesuai }\end{array}$ \\
\hline $\begin{array}{l}\text { Biaya } \\
\text { Ongkos } \\
\text { Angkut }\end{array}$ & $\begin{array}{l}\text { Biaya Angkut } \\
\text { Biaya Pemasaran Rp xxx } \\
\quad \text { Kas Rp xxx }\end{array}$ & $\begin{array}{l}\text { Biaya Angkut masuk } \\
\text { Persediaan Rp xxx } \\
\text { Kas Rp xxx } \\
\text { Biaya Angkut keluar } \\
\text { Biaya angkut keluar Rp xxx } \\
\text { Kas Rp xxx }\end{array}$ & $\begin{array}{l}\text { Tidak } \\
\text { sesuai }\end{array}$ \\
\hline $\begin{array}{l}\text { Pengukur- } \\
\text { an } \\
\text { Persediaan }\end{array}$ & $\begin{array}{l}\text { Hanya mencatat biaya pembelian } \\
\text { antara lain biaya harga beli, biaya } \\
\text { pajak. }\end{array}$ & $\begin{array}{l}\text { Biaya pembelian, biaya konversi } \\
\text { \& biaya lain-lain }\end{array}$ & $\begin{array}{l}\text { Tidak } \\
\text { sesuai }\end{array}$ \\
\hline
\end{tabular}




\begin{tabular}{|c|c|c|c|}
\hline $\begin{array}{l}\text { Teknik } \\
\text { Pengukur- } \\
\text { an } \\
\text { Biaya }\end{array}$ & Metode eceran dan biaya standart & $\begin{array}{l}\text { Metode biaya standar \& metode } \\
\text { eceran }\end{array}$ & Sesuai \\
\hline $\begin{array}{l}\text { Pengakuan } \\
\text { sebagai } \\
\text { Beban } \\
\text { Pengungka- } \\
\text { pan }\end{array}$ & $\begin{array}{l}\text { HPP Rp xxx } \\
\text { Persediaan barang } \\
\text { Pengungkapan Diungkapkan dalam } \\
\text { laporan keuangan } \\
\text { (laporan neraca dan laporan laba- } \\
\text { rugi) }\end{array}$ & $\begin{array}{l}\text { HPP Rp xxx } \\
\text { Persediaan barang Rp xxx } \\
\text { Diungkapkan dalam laporan } \\
\text { keuangan } \\
\text { (laporan neraca dan laporan laba- } \\
\text { rugi) }\end{array}$ & Sesuai \\
\hline
\end{tabular}

Sumber: Data hasil olahan, 2016.

Berdasarkan tabel diatas menunjukkan pencatatan yang sesuai dengan PSAK No.14 Revisi 2012 yaitu pembelian persediaan barang dagangan secara kredit maupun kontan, penjulan barang dagang secara kredit maupun kontan, teknik pengukuran biaya dan pengakuan sebagai beban. Sedangkan yang tidak sesuai dengan PSAK No.14 Revisi 2012 yaitu pencatatan retur penjulan maupun pembelian dan teknik pengukuran persediaan.

\subsubsection{Pembahasan}

Berdasarkan tabel 4.4 diatas menunjukkan bahwa pengakuan pencatatan persediaan barang dagang PT. Bumi Pembangunan Pertiwi menggunkan metode perpetualada yang tidak sesuai dengan pengakuan persediaan berdasarkan PSAK 14 Revisi Tahun 2012 yaitu pencatatan returpembelian yang menambahkan biaya lain-lain ke jurnal pencatatan retur pembelian. Yang dimaksud biaya lain-lain adalah biaya selisih harga karena disetiap periode pembelian terkadang harga pokok pembelian barang ke pabrik berbeda-beda. Sehingga ketika ada retur mengakibatkan di laporan stok persediaan terjadi selisih pada harga pokok pembelian. Pencatatan retur pembelian perusahaan mencatat selisih harga tersebut disisi sebelah kredit dengan keterangan biaya lain-lain.
Sedangkan untuk retur penjualan hanya mencatat disisi sebelah debet retur penjualan dan kas disisi sebelah kredit. Untuk proses retur penjualan perusahaan menerapkan 3 cara yaitu dari pihak kepala gudang membuat Form BPB (Bukti Penerimaan Barang), atau Form FRC (Form Retur Customer) dan bagian customer service perusahaan melakukan pembatalan transaksi. Kurangnya koordinasi kepala gudang dengan custumer service ketika adanya retur menyebabkan terjadi selisih stok. Karena dari pihak customer service membuatkan invoice sesuai dengan PO (Purchase Order) dari customer tersebut.

Menurut PSAK 14 Revisi Tahun 2012 untuk pengukuran persediaaan mencantumkan biaya pembelian, biaya konversi dan biaya lain-lain. Yang termasuk biaya lain-lain yaitu biaya peryimpanan, biaya administrasi dan biaya penjualan. Masalah yang dihadapi perusahaan tidak adanya biaya penyimpanan barang dagangan, biaya yang dimaksud antara lain biaya kerusakan barang dan biaya kehilangan akibat pencurian. Akibat tidak adanya biaya penyimpanan ketika ada semen keras ataupun kehilangan dibebankan pada kepala gudang yang bersangkutan.

Pencatatan biaya ongkos angkut perusahaan mencatat disisi sebelah debet biaya pemasaran dan disisi sebeleh kredit 
kas. Untuk barang kiriman dari pabrik perusahaan tidak mencatat biaya angkut karena perusahaan mendapatkan harga pokok pembelian barang dagang sudah harga yang netto. Sedangkan ongkos angkut penjulan, perusahaan hanya mencatat biaya bahan bakar minyak (BBM) yang dicatat dalam biaya pemasaran. Tidak tercatatnya biaya ongkos angkut pada faktur penjualan menyebabkan perusahaan membebankan ongkos angkut bongkaran semen pada pemilik toko. Sehingga banyak customer yang komplain karena ongkos angkut bongkaran semen yang tidak konsisten karena tenaga bongkar yang mematok harga tidak sesuai dengan anjuran perusahaan.

Sedangkan untuk metode penilaian persediaan PT. Bumi Pembangunan Pertiwi menggunakan metode rata-rata average. Dalam metode average untuk menghitung harga pokok adalah jumlah harga pokok produk awal dikali dengan jumlah persediaan awal. Jika ada pembelian akan menambah stok persediaan barang dagangan. Jika ada penjualan maka akan mengurangi persediaan barang dagang. Metode average membebankan biaya ratarata yang sama pada setiap unit barang yang dibeli maupun dijual. Sehingga memudahkan menghitung harga pokok penjualan per unit dan mengurangi risiko kerugian karena perbedaan harga pokok pembelian setiap periode berbeda-beda. Penggunaan metode average memudahkan perusahaan untuk mencatat penilaian persediaan karena metode average tidak mementingkan apakah barang tersebut masuk pertama atau masuk terakhir.Jika perusahaan menggunakan metode $F I F O$ dan $L I F O$ perusahaan lebih sulit untuk menghitung harga pokok per unit barang dan cenderung mendapatkan.

\section{KESIMPULAN DAN SARAN Kesimpulan}

Dari hasil penelitian yang dilakukan pada PT. Bumi Pembangunan Pertiwi, maka peneliti mengambil beberapa kesimpulan yang dapat dikemukakan yaitu sebagai berikut :

1. Metode pencatatan persediaan barang dagangan PT. Bumi Pembangunan Pertiwi adalah metode perpectual sedangkan metode penilaian persediaan barang dagangan menggunakan metode Average.

2. Kebijakan perusahaan dalam pencatatan dan penilaian persediaan barang dagangan adalah sebagai berikut:

a) Sistem pencatatan persediaan yang di pakai PT. Bumi Pembangunan Pertiwi adalah menggunakan metode perpectual adayang tidak sesuai dengan PSAK 14 Revisi Tahun 2012 yaitu metode pencatatan retur, biaya ongkos angkut dan teknik pengukuran persediaan hanya mencatat biaya harga beli dan biaya pajak.

b) Metode penilaian persediaan yang dipakai PT. Bumi Pembangunan Pertiwi adalah menggunakan metode penilaian average. Metode ini membebankan biaya rata-rata yang sama pada setiap unit barang yang dibeli maupun dijual. Sehingga memudahkan menghitung harga pokok penjualan per unit dan mengurangi risiko kerugian karena perbedaan harga pokok pembelian setiap periode berbedabeda. Dan metode ini telah sesuai dengan PSAK NO 14 Revisi Tahun 2012.

\section{Saran}

Berdasarkan kesimpulan diatas maka peneliti dapat menyampaikan saran untuk perusahaan sebagai berikut: 
1. Bagi peneliti selanjutnya, disarankan mengambil objek lebih dari satu perusahaan sehingga dapat membandingkan dengan perusahaan lain.

2. Bagi manajemen PT. Bumi Pembangunan Pertiwi

a. Disarankan menerapakan metode pencatatan persediaan menggunakan metode perpectualdalam hal pencatatan retur sesuai dengan PSAK NO 14 Revisi Tahun 2012 dan melakukan pemeriksaan terhadap pencatatan retur untuk menghindari salah pencatatan yang bisa mngakibatkan selisih stok.

b. Untuk menghindari sering terjadinya komplain customer, perusahaan disarankan mencatat biaya ongkos angkut penjualan yang dicetak di faktur penjualan sehingga di bagian pengiriman tidak meminta ongkos angkut ke pemilik toko.

c. Perusahaan disarankan mencatat biaya penyimpanan sehingga ketika ada semen keras tidak merugikan perusahaan dan jika ada kehilangan barang sepenuhnya tidak dibebankan pada kepala gudang.

\section{DAFTAR PUSTAKA}

Arikuntoro, Suharsimi.2002. Prosedur Penelitian Suatu Pendekatan Prektik. Edisi revisi VCetakan kedua belas. Rineka Cipta: Jakarta

Djam'an, Satori dan Aan, Komariah. 2012. Metodelogi Penelitian Kualitatif. Cetakan keempa. Jakarta: ALFABETA

Emzir. 2011. Metodelogi Kualitatif Analisis Data. Cetakan kedua: Jakarta

Handoyo Mardianto.2009.Manajemen Keuanngan.BPFE Yogyakarta. Erlangga, Jakarta.
Ikatan Akuntan Indonesia. 2012. Pernyataan Standar Akuntansi Keuangan (Revisi 2012). Jakarta.

Kieso, DonaldE., dkk. 2009. Akuntansi Intermediate. Edisi Keduabelas. Erlangga. Jakarta.

Nikmatus Salamah. 2012. Analisis Pencatatan dan Penilaian Persedian Dengan PSAK 14 Revisi Tahun 2012 Pada UD. Jaya Alumunium.Skripsi: Fakultas Ekonomi Wijaya Putra. Surabaya.

Nurul Fitah Anwar dan Herman Karamoy. 2014. Analisis Metode Pencatatan dan Penilaian Terhadap Persediaan Barang Dagang Menurut PSAK Nol4 pada PT Tirta Investama DC Manado. Jurnal: Fakultas ekonomi Sam Ratulangi Manado.

Rangkuti, Freddy. 2009. Strategi Promosi yang Kreatif dan Analisis. Kasus. Integrated Marketing Communication. PT. Gramedia Pustaka Utama Jakarta.

Reeve, James R., Warren, Carl S., Duchac, Jonathan E., Wahyuni, Ersa T., Soepriyanto, Gatot., Jusuf, Amir A, \& Djakman, Chaerul D. 2009. Pengantar Akuntansi - Adaptasi Indonesia. Buku 1. Salemba Empat, Jakarta Selatan.

Resty Ayu Andhari, Kusni hidayat, Arief Rahman. 2015. Analisis Penerapan Metode Pencatatan dan Penilaian atas Persediaan Barang Dagang pada PT. Inbisco Niagatama Semesta- Krian. Jurnal: Fakultas ekonomi Bayangkara Surabaya.

Sambuaga, S, Reinhard. 2013. Evaluasi Akuntansi Persedian Pada PT. Sukses Era Niaga. Jurnal: Fakultas Ekonomi dan Bisnis. Jurusan Akuntansi Universitas Sam Ratulangi Manado. 
Stice dan Skousen. 2009, Akuntansi Intermediate. Edisi Keenam Belas. Buku 1.Salemba Empat. Jakarta

Sugiyono.2009. Metodelogi Peletian Pendidikan Pendekatan Kualiutatif, Kuantitatif, dan $R$ \& D. Bandung: ALFABETA
Suhayati, Ely dan Anggadini Sri D. 2009. Akuntansi Keuangan. Edisi Pertama. Graha Ilmu. Yogyakarta. Syakur, Ahmad Syafi' I. 2009. Intermediate Accounting dalam Perspektif Lebih Luas. Penerbit Publishep.

Tjahjono, Achmad. 2009. Akuntansi Pengantar 2. Ganbika. Yogyakarta. 